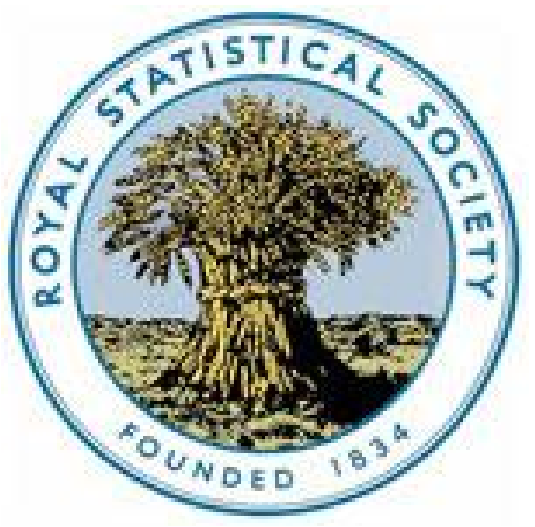

\title{
WILEY
}

\section{The National Expenditure upon Alcohol}

Author(s): Stephen Bourne

Source: Journal of the Statistical Society of London, Vol. 45, No. 2 (Jun., 1882), pp. 297332

Published by: Wiley for the Royal Statistical Society

Stable URL: http://www.jstor.org/stable/2979273

Accessed: 27-06-2016 03:23 UTC

Your use of the JSTOR archive indicates your acceptance of the Terms \& Conditions of Use, available at

http://about.jstor.org/terms

JSTOR is a not-for-profit service that helps scholars, researchers, and students discover, use, and build upon a wide range of content in a trusted digital archive. We use information technology and tools to increase productivity and facilitate new forms of scholarship. For more information about JSTOR, please contact support@jstor.org.

Royal Statistical Society, Wiley are collaborating with JSTOR to digitize, preserve and extend access to Journal of the Statistical Society of London 


\section{The National Expenditure upon Alcohol. By Stephen Botrne, Esq.}

[Read before the Statistical Society, 18th April, 1882.]

\begin{tabular}{|c|c|}
\hline \multicolumn{2}{|c|}{ CON'TENTS: } \\
\hline \multirow{2}{*}{\multicolumn{2}{|c|}{\begin{tabular}{c|c} 
PAGE & \multicolumn{2}{c}{${ }^{\text {PAGE }}$} \\
penditure
\end{tabular}}} \\
\hline & \\
\hline I I.-Progress of Consumption .... 301 & \\
\hline 11I. - Cost of Alcohol Consumed .. 306 & V.-Expenditure Resulting from \\
\hline (a) In Materials Converted 307 & Consumption \\
\hline $\begin{array}{l}\text { (b) In Conversion and Dis- } \\
\text { tribution }\end{array}$ & VI.-Loss of \\
\hline (c) In Supporting Makers & \\
\hline and Distributors $\ldots . .312$ & VII.-Conclusion .............. \\
\hline
\end{tabular}

IF, as is set forth in the constitution of this Society, "it was estab" lished to collect, arrange, digest, and publish facts illustrating "the condition and prospects of society in its material, social, " and moral relations," there can be no more fitting object to which to direct the attention of its Fellows than that which is indicated by the title of this paper. That the material condition of the people of this country is most seriously affected by the drinking customs of society, and that its future prospects are imperilled by a continuance of these customs, is the universal testimony of statesmen, judges, medical men and economists, no less than of clergymen and philanthropists. That the consumption of intoxicating liquors exercises a most important influence upon the social relations of all classes of the community, cannot be doubted by any who are conversant with the effects it produces in the homes and the habits of both rich and poor. There is scarcely a family whose history does not afford evidence of the moral delinquencies resulting from some one or more of its members sacrificing health, happiness, and character to the ensnaring indulgence of drink. To trace out the course of these various results is not the province of this Society, but to inquire into the facts on whose evidence they rest, and to collect sach proof of this wide spread evil as admit of being treated by the numerical method, is clearly within the range of those duties which belong to such a body as ours; and seeing the extent of the evil which exists, and the lamentable influence it exercises upon the national prosperity, it is of the atmost importance 
that the figures which illustrate its progress should be studied and criticised. Thus stamped with authority, they will not fail to be recognised by those who have not the time or the opportunity to ascertain the truth or otherwise of the statements on which their appeals for the promotion of temperance are grounded. An additional reason why this matter should be brought under our notice is to be found in the widely divergent opinions put forth by members of our own bods, and the violation of economic principles in the deductions drawn from but partial investigation, which are given forth to the world and constantly proclaimed as absolute truths. It will be in the recollection of our members that the programme for the session of 1880-81 gave promise of a paper on this subject from the pen of a prominent member of the sister society in Manchester, whose name also is numbered amongst the Fellows here. Personally it is matter of regret to me that the paper so offered was not read, for though full, as I venture to think, of unsound deductions, it would have perhaps been better that the truth should have been elicited here rather than that statements of, to say the least, doubtful authenticity, should have been publicly promulgated without the necessary qualification. I allude to the writings of Mr. W. Hoyle, from whose recent letter to the "Times," 11th March, I quote as follows :-

"Our Annual Drink Bill.-Along with the Board of Trade returns for February, we have also the Excise returns, which enable us to calculate the expenditure upon intoxicating liquors during the year 1881. The following are the particulars thereof. I also give the figures for 1880 :-

\begin{tabular}{|c|c|c|}
\hline \multirow{3}{*}{ 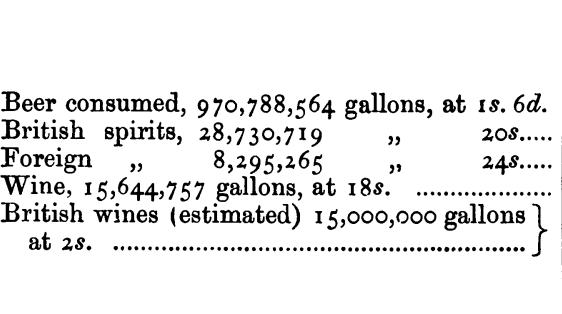 } & 1881. & 1 ' 80. \\
\hline & \begin{tabular}{r}
\multicolumn{1}{c}{$£$} \\
$72,809,142$ \\
$28,730,719$ \\
$9,954,318$ \\
$14,080,281$ \\
$1,500,000$
\end{tabular} & $\begin{array}{c}£ \\
67,881,673 \\
28,457,486 \\
10,173,014 \\
14,267,102 \\
1,500,000\end{array}$ \\
\hline & $127,074,480$ & $122,279,275$ \\
\hline
\end{tabular}

"The total expenditure upon intoxicating liquors of all kinds during the past ten years has been $1,364,818,357 l$., or, in round numbers, $136,500,000 l$. yearly. But if the brewers' corrections be made, it will give $143,600,000 l$. as baving been spent upon intoxicating liqnors during each of the past ten years, or a total of r,436,000,000l. - a sum nearly twice the amount of our national debt. And let it be borne in mind that these figures in no way include any of the indirect costs and losses which result from drinking. These will amount at the very least to another 100 million pounds annually, giving a total cost and loss to the nation from our drink expenditure of over 240 million pounds yearly." 


\section{I.-Personal and National Expenditure.}

Now, although strongly of opinion that the above 127 million pounds is setting the sum of individual expenditure too high, and that probably 100 million pounds would more nearly represent the aggregate of the sums which in the course of the year pass out of the pockets of the consumers into the hands of those from whom they purchase the drink; I do not propose to calculate the precise amount at which it may be estimated. The inquiry would be difficult, because of the variation in the price paid for the drink according to the place or circumstances under which it may be obtained. The man who buys each glass from the publican or the hotel keeper, must necessarily pay much more per gallon than the one who takes it from a cask or bottle at home, and it would be impossible to ascertain how much is drawn from each source. Mr. Hoyle's estimate is supported by the calculations of Professor Leone Levi in a report of a committee of the British Association, with which I was also associated, presented to that body at its meeting last year in York, viz., "The Appropriation of Wages," which will be found full of the most interesting facts and speculations as to the mode in which the earnings or income of the people are expended. The Professor estimates the annual consumption for 1880 to have been :-

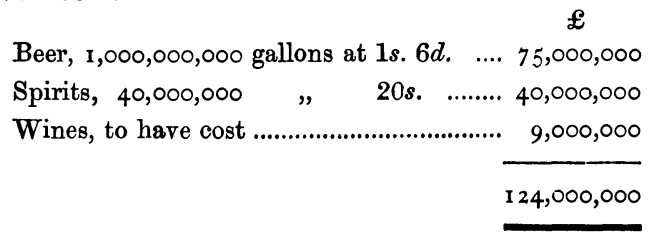

which total very closely agrees with Mr. Hoyle.

The professor whilst thus assuming that the collective expenditure of the respective individuals amounts to this sum-puts the "original cost of home produce and imports" no higher than 42 million pounds. The difference between the two being the contribution to the revenue and the costs of distribution. On the other hand, Mr. Hoyle speaks of the personal and the national expenditure as one and the same thing; as he expresses it, "the " total cost and loss to the nation from our drink expenditure." This will be even more apparent to be his meaning from the following extract from his paper read at the same meeting of the British Association, on "The Economic Influence of the Drinking "Customs of Society upon the Nation's Well-being," when the soundness of his conclusions was disputed by Dr. Levi and others. 
"The next table I will give shows the aggregate direct and indirect loss of wealth resulting from the drinking habits of the population of the United Kingdom during each decade from the year 1830 to 1879 inclusive.

\begin{tabular}{|c|c|c|c|}
\hline Ten Years ending & Direct Expenditure. & $\begin{array}{c}\text { One-half } \\
\text { of Indirect Loss. }\end{array}$ & Total. \\
\hline 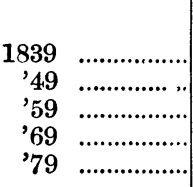 & $\begin{array}{c}£ \\
762,698,7.54 \\
717,208,512 \\
817,041,512 \\
1,020,677,801 \\
1,359,887,808\end{array}$ & $\begin{array}{c}£ \\
381,349,377 \\
358,604,256 \\
408,520,756 \\
510,338,900 \\
679,943,904\end{array}$ & 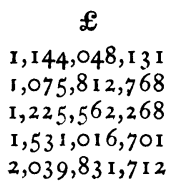 \\
\hline & $4,677,514,387$ & $2,338,757,193$ & $7,0.16,7$ I 2,508 \\
\hline
\end{tabular}

"The following table shows the wealth which would have accrued to the population of the United Kingdom, if the money wasted, as shown above, by the drinking habits of the people during each decade of the past fifty years, had been invested at 5 per cent. per annum, simple interest. It illustrates very powerfully the cumulative loss of wealth owing to our drinking customs :-

$£$ £

\begin{tabular}{|c|c|c|c|c|c|c|}
\hline $\mathrm{I}, 075,812,768$ & $"$ & ' 49 & '79, thirty & ” & $\ldots$ & $\mathrm{I}, 6 \mathrm{I}_{3}, 7 \mathrm{I}_{9}, \mathrm{I}_{5}$ \\
\hline $1,225,562,268$ & $"$ & '59 & '79, twenty & $"$ & $\ldots$ & $1,225,562,268$ \\
\hline $\mathrm{I}, 53 \mathrm{I}, 0 \mathrm{I} 6,70 \mathrm{I}$ & $"$ & '69 & " '79, ten & $"$ & $\cdots \cdot$ & $765,508,350$ \\
\hline $2,039,831,712$ & $"$ & & say for four & $"$ & $\cdots$ & $407,966,342$ \\
\hline מ, מ, 7,016,27 & & & & & & $6,300,852,374$ \\
\hline
\end{tabular}

"Adding this interest to the principal sum we get a total of $13,317,123,954 l$., heing the amount which has been lost to the nation in material wealth hy our drinking labits during the past fifty years.

"In a paper read before the Statistical Society in January of 1878, Mr. Giffen calculates that the total capitalised value of all the property in the United Fingdom amounts to $8,500,000,000 \mathrm{l}$., so that it will be seen that had the money which has been expended in intoxicating liquors during the last fifty years been expended as it ought, the nation's wealth might have been double what it is, with nearly 5 thousand million pounds to spare."

Apart from any question of the accuracy of the data from which these surprising amounts are worked out, it seems to me that the fallacy of the assumption that the "personal" and the "national" expenditure are identical is self-evident. The money which the individual expends is not lost but simply transferred to the pocket of another. The liquor for which he gives his coin, when consumed is gone, and the loss to the nation in an economic sense is the exact amount which has been expended, in its production if of home manufacture or its purchase if procured from abroad. To $s$ it forth as near as may be what this will in the aggregate amount 
to, is the first subject on which I propose to treat; premising that it is with no desire to underrate the efforts which Mr. Hoyle is making in the noble cause of temperance reform, or with any desire to decry the spirit in which he pursues the work, but in the endeavour to correct the errors into which, as it seems to me, he falls, that I undertake this investigation. Rather do I wish to strengthen the hands of those with whom I am, as he is, working together, though not altogether on the same lines, by ascertaining what is the trath, and so avoiding exaggerated statements and untenable arguments, in the prosecution of that which I consider without doubt to be the most prominent and the most serious conflict of the day. A simple illustration will show wherein the difference lies. A master shoemaker pays his workman 5s. for $^{\text {s. }}$ working up ros. worth of leather into a pair of boots, which instead of selling for the sovereign a customer is ready to give, are dropped into the fire, where they are utterly consumed. He has lost not 20s., but I 5s., for the smaller sum will procure him another pair. The nation is the poorer for the leather which is lost and the time wasted; but not by the Ios. and the 5s.-only to the extent which its resources must be drained upon to grow and prepare another piece of leather, and support the workman during the hours he will have to spend in making another pair. One man buys a bottle of wine for $2 s .6 d$., which he pays in cash, another purchases exactly the same article for $3^{s}$. of a different dealer. On Mr. Hoyle's principle that the price paid measures the nation's loss, it would vary 20 per cent., whereas the actual outlay in each case is the same.

It will scarcely be necessary to follow the writer through the calculations of supposed savings and accumulations. The direct expenditure includes the revenue, which would not have been collected had it not been required for spending, and though son $t$ allowance for it is made on the presumed indirect expenditure, in is altogether too vague. Then the investment of such large sums at 5 per cent., or any rate of interest, would clearly be impossible. The nation would only gain by the use of them as capital in promoting industries, the profit from which would result in some actual accumulation or enjoyment of wealth. This is far too uncertain for calculating, as is done so close as even to units of pounds.

\section{II.-Progress of Consumption.}

Before, however, pursuing this analysis, let me lay before you two or three tables depicting the progress of consumption during the last twenty-five years. To go back farther would involve questions as to the data being really similar : indeed, there is great difficulty 
in showing it correctly even for this period. For one reason, the changes from malt to beer duty, and in the mode of ascertaining the amount of proof spirit, have deranged the calculations for the last two years; whilst as regards foreign produce, the alterations in the ratings for daty, and in the practice of obtaining the valuation, have precluded absolute identity. Again, the quantities for the several years may not be quite correct, the two departments of Customs and Excise making up the accounts at different periods, rendering it difficult to show the exact proportions of each year. Some of the accounts are made up for the year ending on the 31st March, others to the 30th September, and others at its natural termination on 31st December. All that can be done is to add together each item for a complete year, though thus they will be overlapping each other, and therefore the comparison between any two years near together must not be relied on; yet the general progress is correct.

In the first table are shown the quantities of each description, separating the foreign from the home manufacture, classifying the spirits, wine, and beer, but reducing the whole to the quantity of proof spirit which, as the result of careful calculation, may have been actually consumed. Spirits are charged for duty at the proof gallon, wine at the liquid gallon according to certain ranges of strength, which have been duly considered, and the average taken on the actually ascertained degrees of spirit in the importations of one specific year (1875). Beer until recently has been assumed from the quantities of malt consumed, at the rate of two bushels to the barrel of 36 gallons, and its strength computed as 10 degrees of proof spirit in each gallon, that is, one-tenth the alcoholic strength of spirits as charged for duty. It will be noticed that there has been a progressive increase quite out of proportion to the growth of population up to 1876 , about which time the consumption reached its maximum. Since then there has been a decline; but owing to the changes in the mode of levying the duty, too much dependence must not be placed on the figures for 1881. Malt duty was charged before brewing, with some credit for payment of duty, and there were drawbacks to settle. Beer is charged when brewed, and paid at once or soon after. 
TABLE I.-Quantities of the several Descriptions of Alcoholic Liquors taken for Consumption in each Year from 1857 to 1881, showing the Total Quantity of Proof Spirit contained therein.

[In millions to two decimals.j]

\begin{tabular}{|c|c|c|c|c|c|c|}
\hline \multirow{2}{*}{ Year. } & \multicolumn{3}{|c|}{ Foreign. } & \multicolumn{2}{|c|}{ Home. } & \multirow{2}{*}{$\begin{array}{c}\text { Equivalent } \\
\text { to } \\
\text { Proof Spirit. }\end{array}$} \\
\hline & Spirits. & Wine. & Beer. & Spirits. & Beer. & \\
\hline $1857 \ldots$ & $\begin{array}{l}\text { Galls. } \\
473\end{array}$ & $\begin{array}{l}\text { Galls. } \\
6 \cdot 60\end{array}$ & $\begin{array}{c}\text { Galls. } \\
0 \cdot 11\end{array}$ & $\begin{array}{l}\text { Galls. } \\
23.56\end{array}$ & $\begin{array}{l}\text { Galls. } \\
632 \cdot 16\end{array}$ & $\begin{array}{l}\text { Galls. } \\
93.79\end{array}$ \\
\hline$' 58 \ldots$ & $45^{8}$ & $6 \cdot 27$ & $0 \cdot 11$ & 23.99 & $672 \cdot 84$ & $98 \cdot 01$ \\
\hline '59 .... & $4 \cdot 93$ & $6 \cdot 78$ & $0 \cdot 12$ & $22 \cdot 60$ & $669 \cdot 24$ & 96.78 \\
\hline '60 .... & $55^{2}$ & $6 \cdot 72$ & $0 \cdot 13$ & $24 \cdot 44$ & $709 \cdot 56$ & $103 \cdot 23$ \\
\hline '61 .... & $5 \times 19$ & 10.69 & $0 \cdot 11$ & $19^{\circ} 64$ & $684: 72$ & $97 \cdot 02$ \\
\hline '62 .... & $5^{\cdot 19}$ & $9 \cdot 76$ & $0 \cdot 10$ & $19: 94$ & $704 \cdot 16$ & $99^{\circ} 03$ \\
\hline '63 .... & 557 & $10 \cdot 42$ & 0.06 & 18.88 & $705 \cdot 24$ & $98 \cdot 62$ \\
\hline '64,... & 6.30 & $11 \cdot 40$ & $0 \cdot 13$ & $19^{\circ} 42$ & $713 \cdot 52$ & $101 \cdot 04$ \\
\hline '65 .... & 6.74 & $11 \cdot 99$ & $0 \cdot 11$ & $20 \cdot 38$ & $792 \cdot 72$ & $110^{\circ} 53$ \\
\hline '66 .... & $7 \cdot 80$ & $13 \cdot 24$ & 0.08 & 20.98 & $892 \cdot 08$ & $122 \cdot 28$ \\
\hline '67 .... & $8 \cdot 34$ & $13 \cdot 67$ & $0 \cdot 14$ & $22 \cdot 15$ & $885 \cdot 96$ & $123^{\circ} 44$ \\
\hline '68 .... & 8.40 & $15 \cdot 06$ & $0 \cdot 14$ & $21 \cdot 02$ & $855 \cdot 00$ & $119^{\circ} 5^{8}$ \\
\hline '69 .... & $8 \cdot 17$ & $14 \cdot 73$ & $0 \cdot 18$ & $2 I \cdot I I$ & $864: 72$ & 120.39 \\
\hline '70 .... & $8 \cdot 44$ & $15 \cdot 08$ & $0 \cdot 18$ & $21 \cdot 98$ & $883 \cdot 44$ & $123^{\circ} 47$ \\
\hline '71 .... & $8 \cdot 93$ & $16 \cdot 14$ & $0 \cdot 15$ & $22 \cdot 96$ & $931 \cdot 68$ & 130.06 \\
\hline '72 .... & 9.07 & $16 \cdot 77$ & $0 \cdot 16$ & $24 \cdot 59$ & $999 \cdot 36$ & $1_{3} 8 \cdot 8 t$ \\
\hline $73 \ldots$. & 10.26 & $17 \cdot 91$ & $0 \cdot 18$ & 27.56 & $1,051 \cdot 56$ & $14^{8} \cdot 4^{6}$ \\
\hline $74 \ldots$ & 10.68 & $17 \cdot 17$ & $0 \cdot 17$ & $29^{\circ} 3 \mathrm{I}$ & $1,082 \cdot 52$ & 153.56 \\
\hline '75 .... & $11 \cdot 85$ & $17 \cdot 24$ & $0 \cdot 17$ & $29^{\circ} 82$ & $1,096 \cdot 20$ & 156.63 \\
\hline '76 .... & $1 \mathrm{I} \cdot 55$ & $18 \cdot 54$ & $0 \cdot 18$ & 30.30 & $1,143 \cdot 72$ & $161 \cdot 71$ \\
\hline $77 \ldots$. & 10.73 & $17 \cdot 57$ & $0 \cdot 21$ & $29 \cdot 80$ & $1,132 \cdot 92$ & $15^{\circ} 99$ \\
\hline '78 .... & 10.55 & $16 \cdot 17$ & $0 \cdot 22$ & 30.28 & $1,138 \cdot 68$ & $159^{\circ} 45$ \\
\hline '79 .... & $9 \cdot 5^{8}$ & $14 \cdot 80$ & $0 \cdot 25$ & 28.93 & $1,055 \cdot 16$ & 148.33 \\
\hline '80 .... & $8 \cdot 53$ & $15 \cdot 75$ & 0.38 & $27^{\circ} 29$ & $1,091 \cdot 52$ & $149^{\circ} 42$ \\
\hline '81 .... & $8 \cdot 30$ & $15 \cdot 64$ & 0.46 & 28.80 & $970 \cdot 78$ & $138 \cdot 60$ \\
\hline Total .... & $199^{\circ} 93$ & $336 \cdot 11$ & $4 \cdot 23$ & $609 \cdot 73$ & $22,359 \cdot 46$ & $3,151 \cdot 23$ \\
\hline Average & $8 \cdot 00$ & $13 \cdot 44$ & $0 \cdot 17$ & 2439 & $894: 38$ & 126.05 \\
\hline
\end{tabular}

Table II gives the revenue derived from the duties levied on each description of liquor for the same period, with the ascertained population, the total amount of duty, and the average sum contributed per head. Here again 1876 yields the maximum, thus corroborating the larger consumption of the previous table, and dividing 
304. Botrne-On the National Expenditure upon Alcohol. [June,

to exactly $\mathrm{I} l$. for each person. The figures for 1881 are so near to those of 1880 as to justify the observation before made as to the comparison of that year with its predecessor.

TABLE II.-Revenue Derived from the Consumption of Alcoholic Liquors in each Year ended 31st March, 1857-81, with the Average Amount per Head of Population.

[In millions of $\mathscr{E}$ 's to two decimals.]

\begin{tabular}{|c|c|c|c|c|c|c|c|}
\hline Year. & Population. & Spirits. & Wine. & Beer. & Licenses. & Total. & $\begin{array}{l}\text { Per Head } \\
\text { it Shillings. }\end{array}$ \\
\hline & & $£$ & $£$ & $£$ & $£$ & $£$ & $\begin{array}{l}\text { Units and } \\
\text { one decinal. }\end{array}$ \\
\hline $1857 \ldots$ & $28^{\circ} 19$ & $11 \cdot 44$ & 2.02 & $6 \cdot 11$ & I'05 & $20 \cdot 62$ & 14.6 \\
\hline '58 .... & $28 \cdot 39$ & $11 \cdot 26$ & 173 & $5 \cdot 79$ & 1.06 & $19 \cdot 84$ & $13^{\circ} 9$ \\
\hline '59 .... & $28 \cdot 59$ & $11 \cdot 23$ & $x \cdot 76$ & 6.01 & I.06 & 20.06 & $14^{\circ} \circ$ \\
\hline$' 60 \ldots$. & 28.78 & $12 \cdot 30$ & $1 \cdot 63$ & 6.72 & 1.08 & $21 \cdot 73$ & I $5^{\circ} \mathrm{I}$ \\
\hline '61 .... & 28.97 & $11 \cdot 85$ & $I \cdot 14$ & $6 \cdot 36$ & $1 \cdot 10$ & $20 \cdot 45$ & $14^{\circ} \mathrm{I}$ \\
\hline '62 .... & 29.20 & i $2 \cdot 27$ & J'ro & $5 \cdot 87$ & I'IO & $20 \cdot 34$ & 139 \\
\hline '63 .... & 29.40 & $12 \cdot 11$ & $I \cdot 14$ & $5 \cdot 39$ & $1 \cdot 35$ & $19 \cdot 99$ & 13.6 \\
\hline '64.... & 29.57 & $12 \cdot 68$ & I 24 & $6 \cdot 09$ & 140 & $21 \cdot 41$ & 145 \\
\hline '65. & $29 \% 77$ & $13 \cdot 48$ & $I \cdot 32$ & $6 \cdot 39$ & $1 \cdot 44$ & $22 \cdot 63$ & I $5^{\circ} 2$ \\
\hline '66 .... & 30.08 & $13 \cdot 94$ & $1 \cdot 41$ & $6 \cdot 43$ & $I \cdot 50$ & $23 \cdot 28$ & 15.5 \\
\hline '67 ..... & 30.33 & $15 \cdot 03$ & I.39 & $6 \cdot 85$ & 1.57 & $24 \cdot 84$ & 16.4 \\
\hline '68 .... & 30.62 & $14 \cdot 81$ & 147 & 6.37 & $r \cdot 59$ & $24: 24$ & $15^{\circ} 8$ \\
\hline '69.. & 30.91 & $14 \cdot 89$ & $1 \cdot 52$ & 6.59 & $1 \cdot 63$ & $24 \cdot 63$ & 159 \\
\hline $70 \ldots$. & $3 I \cdot 2 I$ & $15 \cdot 16$ & $1 \cdot 48$ & $6 \cdot 54$ & 1.66 & $24: 84$ & I $5^{\circ} 9$ \\
\hline '71 .... & 31.51 & $15 \cdot 88$ & $1 \cdot 58$ & $7 \cdot 07$ & $1 \cdot 74$ & $26 \cdot 27$ & 16.7 \\
\hline$' 72 \ldots$. & $31 \cdot 84$ & 16.80 & 1.65 & 6.77 & 1.77 & $26 \cdot 99$ & $17^{\circ} 0$ \\
\hline '73 .... & 32.12 & 18.63 & 1.69 & $7 \cdot 69$ & 1.82 & $29 \cdot 85$ & $18 \cdot 6$ \\
\hline $74 \ldots$ & $32: 43$ & 19.97 & 179 & $8 \cdot 03$ & $1 \cdot 84$ & $31 \cdot 63$ & 19.5 \\
\hline $75 \ldots$ & $32 \cdot 75$ & 20.61 & $1 \% 72$ & $8 \cdot 22$ & 1.86 & $32 \cdot 41$ & 19.8 \\
\hline '76 .... & 33.09 & $21 \cdot 30$ & $1 \cdot 75$ & $8 \cdot 16$ & $1 \cdot 83$ & $33 \cdot 04$ & $20^{\circ} 0$ \\
\hline '77 .... & $33^{\circ} 45$ & 20.64 & $I \cdot 74$ & $8 \cdot 53$ & 1.87 & $32 \cdot 78$ & I9.6 \\
\hline $78 \ldots$ & 33.80 & 20.68 & $x \cdot 63$ & $8 \cdot 25$ & 1.89 & $32 \cdot 45$ & 19.2 \\
\hline '79 .... & $34^{\circ} 16$ & $19 \cdot 74$ & 147 & 8.38 & 1.89 & $31 \cdot 48$ & $18 \cdot 4$ \\
\hline '80 .... & 3447 & $18 \cdot 31$ & I.39 & $7 \cdot 36$ & $\mathrm{I} \cdot 88$ & 28.94 & 16.8 \\
\hline '81 .... & 3479 & $18 \cdot 84$ & $\mathrm{I} \cdot 38$ & $6 \cdot 66$ & $I^{\circ} 96$ & $28 \cdot 84$ & I $6 \cdot 6$ \\
\hline Total .... & - & $393 \cdot 85$ & $38 \cdot 14$ & $172 \cdot 63$ & $38 \cdot 94$ & $643 \cdot 56$ & 410.6 \\
\hline Average & - & $15 \cdot 75$ & $\mathrm{I} \cdot 53$ & $6 \cdot 91$ & $I \cdot 56$ & $25 \cdot 75$ & 16.4 \\
\hline
\end{tabular}

Table III shows the quantities of grain and other materials converted into beer and spirits during the same series of years, the quantity of grain being calculated from the malt used. It is taken from a paper of my own "On the Increasing Dependence of this "Country on the Foreign Supplies of Food,"* with the recent years worked out from similar data. It is probable that the estinates are rather too high, but the progress of successive years may be depended upon; and again, as it should be, 1876 appears as that of

* "Trade, Population, and Food," pp. 76-102. G. Bell and Sons. 
greatest quantity, though in value below 1875 , owing to the fluctuations in price.

TABLE III.-Quantities and Value of Grain Converted into Beer and Spirits, also of Sugar and Molasses.

[In millions to two decimals.]

\begin{tabular}{|c|c|c|c|c|}
\hline Years. & Grain. & Value. & Sugar and Molasses. & Value. \\
\hline 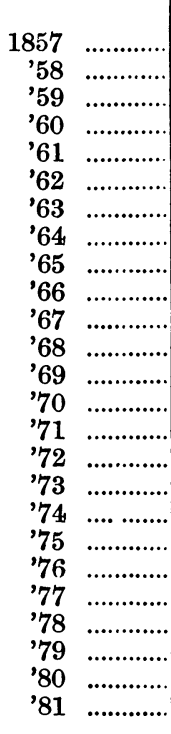 & 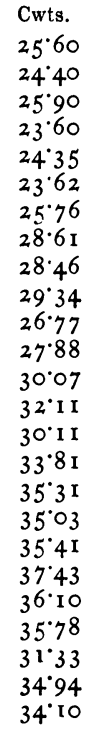 & \begin{tabular}{r}
\multicolumn{1}{|c}{} \\
$10 \cdot 88$ \\
$9 \cdot 13$ \\
$9 \cdot 20$ \\
$10 \cdot 02$ \\
$9 \cdot 91$ \\
7.36 \\
$9 \cdot 05$ \\
$9 \cdot 55$ \\
$9 \cdot 50$ \\
$11 \cdot 25$ \\
$12 \cdot 19$ \\
$13 \cdot 43$ \\
$11 \cdot 55$ \\
$12 \cdot 32$ \\
$11 \cdot 74$ \\
$12 \cdot 84$ \\
$13 \cdot 77$ \\
$15 \cdot 41$ \\
$14 \cdot 97$ \\
$13 \cdot 10$ \\
$13 \cdot 00$ \\
$11 \cdot 81$ \\
$10 \cdot 03$ \\
$11 \cdot 53$ \\
$11 \cdot 60$
\end{tabular} & 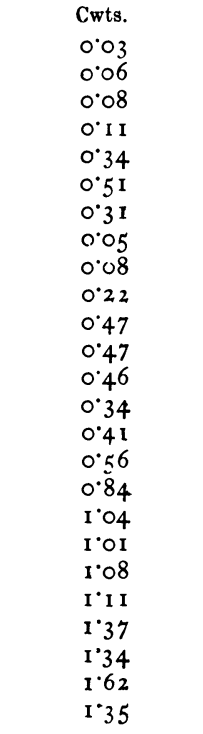 & 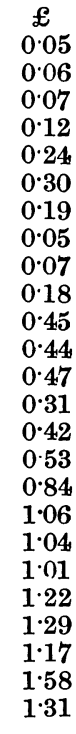 \\
\hline & $755^{\circ} 82$ & $285 \cdot 04$ & $15 \cdot 26$ & $14 \cdot 47$ \\
\hline Averages ......... & 30.23 & $11 \cdot 40$ & $0.6 \mathrm{r}$ & 0.58 \\
\hline
\end{tabular}

Table IV is designed to show the average quantity of proof spirit consumed by each individual of whatever age or sex. If both males and females below the age of 18 are excluded, and only half the females counted-on the presumption that at least twice as much is drunk by a man as by a woman-the gallons will require to be multiplied by 2.33 to give the quantity allotted to each one old enough to be a consumer. Thus the $4^{.89}$ gallons of 1876 will become $11 \frac{1}{2}$ gallons for each adult male, and so in proportion in other years. The relative numbers of the sexes are taken to be in the ratio ascertained by the census of 1871 ; the rise and declension may thus be traced: 1876 being that in which the greatest average quantity seems to have been imbibed. 
TABLE IV.-Average Quantity per Head of Proof Spirit contained in the Various Alcoholic Liquors Consumed in each Year, from 1857 to 1881.

[In single gallons to two decimals.]

\begin{tabular}{|c|c|c|c|c|c|c|}
\hline $1857 \ldots \ldots$. & \multirow{9}{*}{$\begin{array}{l}3.33 \\
3.45 \\
3.39 \\
3.59 \\
3.35 \\
3.39 \\
3.35 \\
3.42 \\
3.71 \\
4.01\end{array}$} & \multirow{9}{*}{\multicolumn{2}{|c|}{ 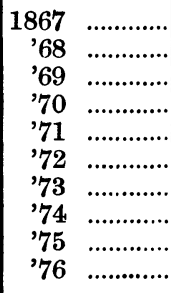 }} & \multirow{9}{*}{$\begin{array}{l}4 \cdot 07 \\
3 \cdot 91 \\
3 \cdot 89 \\
3 \cdot 96 \\
4 \cdot 13 \\
4 \cdot 36 \\
4 \cdot 62 \\
4 \cdot 74 \\
4 \cdot 78 \\
4 \cdot 89\end{array}$} & \multirow{9}{*}{ 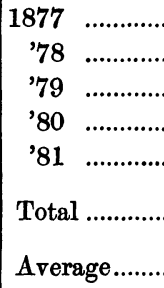 } & 4.74 \\
\hline '58 ........... & & & & & & $\begin{array}{l}4.14 \\
472\end{array}$ \\
\hline '59 ......... & & & & & & 4.34 \\
\hline '60 ........... & & & & & & $\begin{array}{l}4.34 \\
4.33\end{array}$ \\
\hline '61 .............. & & & & & & $\begin{array}{l}435 \\
2.08\end{array}$ \\
\hline $\begin{array}{l}\prime 62 \\
' 63 \ldots \ldots . . . . . . \\
\end{array}$ & & & & & & \\
\hline ' $64 \ldots \ldots . . . . .$. & & & & & & 100.45 \\
\hline '65 .......... & & & & & & \\
\hline '66 .......... & & & & & & $4^{\circ} 02$ \\
\hline
\end{tabular}

All these tables have been grouped together as historical in their character. The particulars they contain may be subsequently referred to, although the further remarks will be principally based upon the information respecting last year. They all, as in the case of subsequent figures where not stated in fnll, are shown in millions to two places of decimals, that system of notation having many advantages in clearness of description and facility in reading, wherever the numbers are so large as that we may dispense with the figure below thousands, which would form the third decimal place where the whole number represents millions.

\section{III.-Cost of Alcohol Consumed.}

In estimating the cost of the alcohol consumed by the people of the United Kingdom, it is not my intention to dwell so much upon the actual money expended upon its production, as upon the proportion of the producing power of the nation which is so employed. To express this in its monetary value even if possible, must fail to give any real idea of the actual cost, unless brought into comparison with the income or resources we possess, and so to show the portion thus absorbed. Values, however, may be useful in some stages of the process, as a means of bringing the several items together. The census of 1881 , although completed so far as the actual numbering is concerned, is not yet so sufficiently advanced as to divide the people into their several classes and occupations. It is necessary, therefore, to fall back upon the details of that of 1871 , and in so doing I shall avail myself of minute calculations made some few years back for a paper on "the Growth of Population "with Relation to the Means of Subsistence," read by myself in Section F of the British Association.* For reasons there set forth, the population was separated into two divisions-the one, in round

* The method adopted is fully explained in this paper, which will be found at pp. 112-32 of the volume before referred to, "Trade, Population, and Food." 
numbers ten and a-half millions, being engaged in producing the various things necessary for consumption, or constituting the material wealth of the country; the other, numbering twenty-one millions, being consumers or possessors only of that which the former section has by its labour created. If we can ascertain with any approach to accuracy how many of the first class are occupied in the preparation and sale of alcoholic liquors, we shall gain a very good idea of the real cost at which they are procured.

\section{(a) In Materials Converted.}

The first stage in such an inquiry is into the materials of which these are composed, for notwithstanding recent vague assertions that an infinitesimal trace of alcoholic existence is to be found in water and other substances, all the alcohol of which we know anything as an article of consumption is manufactured either from farinaceous or saccharine produce. It is in every case formed from the destruction or breaking up of articles of vegetable growth, and their recombination by the art of the distiller or brewer into the various forms of intoxicating drinks of which we make use. With the exception of wine, and so much of the spirit sold as brandy as is distilled from the juice of the grape, all the substances employed other than sugar are indifferently of home or foreign growth; and so far as those of home manufacture are concerned, we may consider them to be either native or imported. The quantities are ascertained from the Excise returns, and the recorded values of the importations from abroad afford the best criterion of money value. Those of foreign manufacture, whether fully prepared for use or as adjuncts to further operations here, are included in the Customs returns, and there is little difficulty as to either their value or quantity. The disturbance following upon th change of duty from malt to beer, before alluded to, renders it doubtful how far the home figures for 1881 truly represent the present consumption. In the following table the figures for 1876 are placed side by side with last year's. It is somewhat uncertain whether the marked diminution actually betokens diminished consumption or accidental difference only, for it is impossible to ascertain whether the stocks in existence at the commencement and the end of the years were alike. When we see that there is a greater falling off in the value of the foreign than the British, it would seem that less has been drunk, but with this the failure of the grape crops in France may have much to do. The lesser quantity of malt and corn used in brewing, whilst that for distilling is nearly as much as before, would indicate the cause to be the change of duty. Either way, the difference is not so great as to affect the calculations 
of which they are to be the basis, and the mean of the two years may be taken as correct.

Until the year 1847 no materials except malt and hops were permitted to be used in the brewing of beer for sale. Then sugar was allowed, and now there is no restriction upon the use of grain of any description. By excise regulations a bushel of malt or corn is to weigh $42 \mathrm{lbs}$., and $28 \mathrm{lbs}$. of sugar is deemed to be equivalent to a bushel of malt. Reducing these to cwts. we have-

$$
\begin{aligned}
& \text { 1876. - Malt and corn............. } 74.85 \text { bushels }=28.07 \text { cwts. } \\
& \text { Sugar and molasses.... } 1.09 \text { cwts. }=\mathrm{I} \cdot 63 \text { " of malt } \\
& \text { 1881.-Malt and corn............. } 67 \cdot 15 \text { bushels }=\frac{29 \cdot 70}{25^{\circ} 18} " \\
& \text { Sugar and molasses.... } 1.41 \text { cwts. }=2 \cdot 11 " \text { of malt } \\
& 27 \cdot 29
\end{aligned}
$$

or taking the mean, $28 \frac{1}{2}$ million cwts., exactly one-half of the average importation of cereals other than wheat for each of the last ten years, or nearly one-fourth of those of home growth, as estimated by Mr. Caird at 122 million cwts.

The next table gives (A) the quantities and values of the grain and saccharine matters of which the beer and spirits we manufactured in the years 1876 and 1881 were composed. It also shows (в) the importations of spirits, wine, and beer from abroad during the same two years: the declared value for the whole-for thus only can they be expressed in one sum-being 8.80l. for 1876, and $74^{\circ} \mathrm{Ol}$. for 1881 ; or taking the mean, a little over 8 millions of money, to be added to $14^{\circ} 10 l$. and $13.08 l$., the values for the two

\begin{tabular}{|c|c|c|c|c|}
\hline \multirow[b]{3}{*}{$\begin{array}{l}\text { Brewing- } \\
\text { Malt and corn } \\
\text { Sugar and molasses } \ldots . . . . . . . . . . . . . . . . . . . .6 \text { cwts. }\end{array}$} & \multicolumn{2}{|c|}{ Quantities. } & \multicolumn{2}{|c|}{ Values. } \\
\hline & 1876. & 1881. & 1876. & 1881. \\
\hline & $\begin{array}{r}\mathbf{5 9} \cdot 30 \\
0.87\end{array}$ & $\begin{array}{r}52 \cdot 33 \\
1 \cdot 15\end{array}$ & $\begin{array}{c}\stackrel{£}{\&} \\
10 \cdot 50 \\
0 \cdot 90\end{array}$ & $\begin{array}{l}\mathscr{E} \\
8 \cdot 84 \\
I \cdot 21\end{array}$ \\
\hline $\begin{array}{l}\text { Distilling - } \\
\text { Malt .................................... bshls. } \\
\text { Grain ............................ cwts. } \\
\text { Sugar and molasses } \quad . . . . . . . . . . . \quad ~\end{array}$ & $\begin{array}{l}6 \cdot 80 \\
8 \cdot 75 \\
0 \cdot 22 \\
\end{array}$ & $\begin{array}{l}6.70 \\
8 \cdot 12 \\
0.26\end{array}$ & $\begin{array}{l}2 \cdot 60 \\
0 \cdot 10\end{array}$ & $\begin{array}{l}2 \cdot 76 \\
0 \cdot 27\end{array}$ \\
\hline 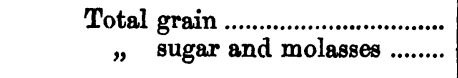 & $\begin{array}{r}74 \cdot 85 \\
1 \cdot 09\end{array}$ & $\begin{array}{r}67 \cdot 15 \\
1 \cdot 41\end{array}$ & $14 \cdot 10$ & $13 \cdot 08$ \\
\hline
\end{tabular}
years respectively of the materials used in home manufacture.

TABLE V.-(A) Materials Used in Brewing and Distilling in the United Kingdom in the Years ended 30th September, 1876 and 1881.

[In millions to two decimals.] 
(в) Alcoholic Liquors. Duty Paid for Consumption in the United Kingdom in the Years ended 31st December, 1876 and 1881.

[In millions to two decimals ]

\begin{tabular}{|c|c|c|c|c|}
\hline \multirow[b]{3}{*}{ 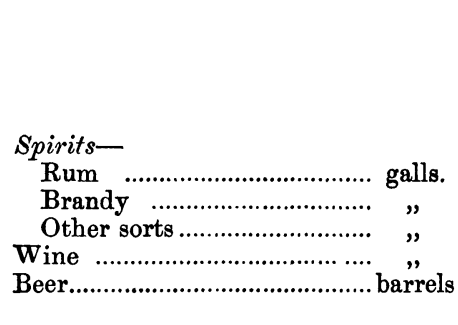 } & \multicolumn{2}{|c|}{ Qunntities. } & \multicolumn{2}{|c|}{ Values. } \\
\hline & 1876. & 1881. & 1876. & 1881. \\
\hline & $\begin{array}{r}5 \cdot 04 \\
4 \cdot 49 \\
2 \cdot 02 \\
18 \cdot 54 \\
0 \cdot 01\end{array}$ & $\begin{array}{r}4.59 \\
3.12 \\
0.59 \\
15.64 \\
0.05\end{array}$ & $\begin{array}{l}£ \\
0 \cdot 52 \\
1 \cdot 48 \\
0 \cdot 27 \\
6 \cdot 50 \\
0 \cdot 03\end{array}$ & $\begin{array}{l}£ \\
1 \cdot 4 \mathrm{I} \\
0.46 \\
0.06 \\
5 \cdot 42 \\
0.05\end{array}$ \\
\hline & - & - & $8 \cdot 80$ & $7 \cdot 40$ \\
\hline Total values $(\mathrm{A})$ and $(\mathrm{B})$ & - & - & $22 \cdot 90$ & $20 \cdot 48$ \\
\hline
\end{tabular}

Bringing together the two sets of values, we have for 1876 $22^{\circ} 90 l$., and for $1881{ }^{20} 48 l$. To these must be added for hops, yeast, and other minor articles of the quantities of which there is no record kept, at least 2 or 3 millions more; and thus it is certain that the cost of the materials for manufacture and the liquors imported cannot be stated at less than 25 million pounds per annum. Professor Leone Levi in the paper already mentioned, estimates the "original cost of home produce and imports of beer, " spirits, and wines together at $\mathbf{4 2 , 8 0 0 , 0 0 0 l . " ~ I n ~ t h i s ~ h e ~ i n c l u d e s ~}$ the expense of manufacture, but not that of retailing, or " distri" bution." What these may be we shall perhaps be able to see farther on; apparently the two estimates are not inconsistent with each other.

Now Mr. Caird calculates the whole value of home agricultural food produce consumed annually to be 230,237,500l., but for reasons fully explained elsewhere, I would deduct 38 million pounds for the value of imported food for cattle, and manures, \&c., for the ground. Again, he does not include a variety of articles such as wood, wool, flax, \&c., used in the manufactures, which I had also previously reckoned at one-fourth of all that is raised at home by the industry of our agricultural labourers. Making these alterations the calculation will stand thus :-

\begin{tabular}{|c|c|}
\hline 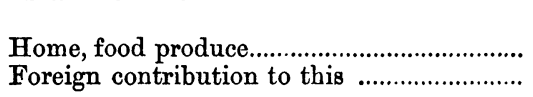 & $\begin{array}{c}£ \\
230,000,000 \\
38,000,000\end{array}$ \\
\hline \multirow[t]{2}{*}{ Add one-third for other growths ......... } & $\begin{array}{r}192,000,000 \\
64,000,000\end{array}$ \\
\hline & $256,000,000$ \\
\hline
\end{tabular}

To raise produce to this value, it appears from the census of 1871 that the population actually engaged in agriculture numbered

VOL. XLV. PART II. 
$2,989,154$. If then the value of the materials and imported liquor be according to the previous calculation 25 millions, say one-tenth of the full produce of the soil, we must in like manner divide the labourers employed upon the soil by ten, bringing out this result, that from 290,000 to 300,000 individuals must be devoting their time and strength to the cultivation of the grain which is ultimately converted into alcoholic drink, and of that which, though not so converted, being equivalent in value to the manufactured liquor imported from abroad, is appropriated to the payment of that which is thus brought into the country. The first item then of cost to the nation is the producing power of some 300,000 of its living producers.

\section{(b) In Conversion and Distribution.}

To ascertain the cost at which the various substances are converted into alcoholic liquors, and they, together with those imported from abroad, are placed within reach of the consumer, it is necessary to resort to that portion of the census report which distributes the population amongst the various occupations which are connected with this traffic. The following list furnishes the description and numbers of those so employed in England and Wales:-

TABLe VI.-Number of Persons in England and Wales Occupied in the Production and Distribution of Alcoholic Liquors, according to Census of 1871.

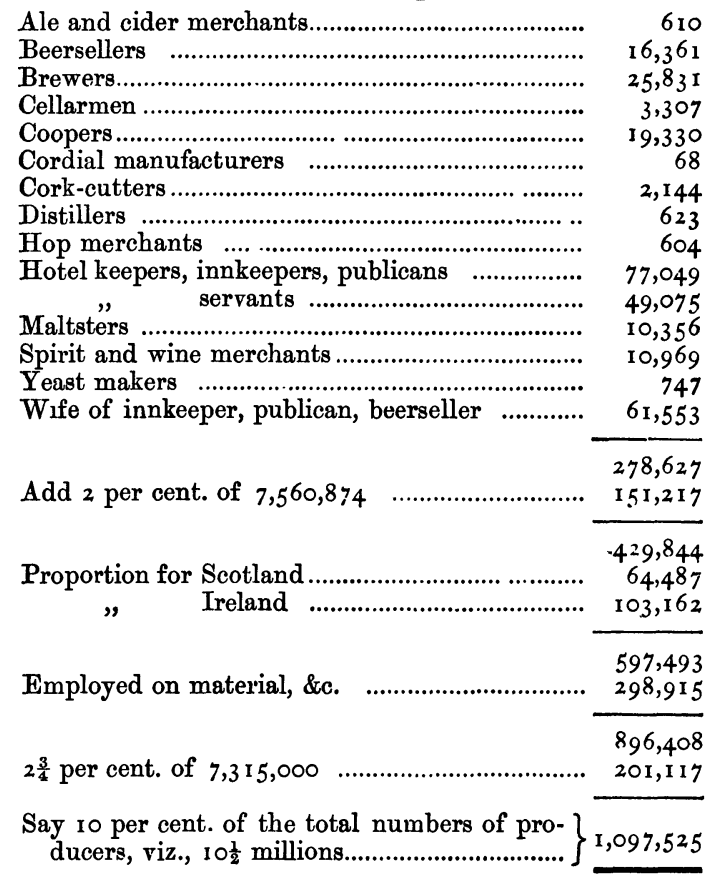


Of the numbers included in the above table, there are several who are only rendering partial service in this way, such as publicans' wives, although only those are enumerated who are stated to be employed in assisting their husbands, \&c. There are others excluded, a portion of whose time properly belongs to this work, e.g., grocers and confectioners, whose numbers are I I I,094 and I6,988. The exclusion of these, by whom a large sale of drink is carried on, will fully if not more than compensate for the inclusion of those referred to, and we may fairly conclude that the whole of the 278,627 does not represent more than the number of those whose entire labour is given to the making and serving alcoholic liquors.

Beyond these there is a large proportion of those engaged in other occupations, whose services are called into requisition for the same end. Public houses, breweries, and distilleries have to be built and maintained. The railway and cartage work in removing from place to place both the materials for manufacture and the manufactured material; the glass and metal trades, as well as the furniture dealer, find large employment in furnishing their respective supplies. A safe method of estimating to what extent this is done would seem to be in supposing that all the several branches of industrial occupation are called into requisition in proportion to the numbers of those actually employed in the trades as shown in the table. Now as these amount to 278,627 , who may be deemed to be of adult age, and the whole of those who were of 18 years and upwards in 1871 was $13,354,191$, of which 278,627 is $2 \cdot 1$ per cent., and the total of the industrial and commercial class together being 7,560,874, 2 per cent. of this number $=15$ I, 2 I 7 , may be appropriated to the service of the makers and dealers in liquor, giving a total of 429,844 for this portion of the kingdom.

It unfortunately happens that the Scotch records differ in many particulars of construction from the English, so that precisely similar information cannot be gained from them. It seems strange that in so simple a work as numbering the people a uniform system could not have been agreed upon. To illustrate the difference that exists : the industrial class for England includes those only who labour in some constructive branch; mere sellers are placed with the domestic or those rendering personal service to their fellows. In the Scotch the order is altered; they thus appear in different categories. Again, the English numbers for each order include all who are returned as working in that particular line, whilst in the Scotch there is an entry in one sum for dependents upon two or three divisions. In consequence of this divergence, it has been thought best to calculate the numbers for both Scotland and Ireland in exact proportion to the total population of each division, which brings out 
64,487 for the one and 103,162 for the other; these, added to those for England, swell the number to 597,493 as that which properly mepresents the total of workers in the manufacturing and dispensing processes. Adding to this 298,915 found before as those by whom the materials for manufacture were produced, with those also given in exchange for the purchases from abroad, we get 896,408 as the estimated portion of the population whose occupation it is to provide the liquor consumed in the land.

\section{(c) In Supporting Makers and Distributors.}

Still this does not complete the tale. Those whose attention is absorbed in producing these drinks, have to depend upon others to provide their food and necessaries to the number of 201,117 persons. This is arrived at by the computation that whereas there are I $\frac{1}{2}$ million producers altogether, of whose labour 70 per cent. viz., $7,315,000$ is required to procure food and necessaries for the whole population of $31 \frac{1}{2}$ millions, and the 896,408 is $2 \frac{3}{4}$ per cent. of this quantity, so $2 \frac{3}{4}$ per cent. of the 7,315,000, by whose labour the whole of the community is snstained, housed, and clothed, will be required to do these offices for workers in alcohol, thus swelling the total to $1,097,525$, which is slightly beyond 10 per cent. of the full number of producers the kingdom contains. This calculation is singularly in accord with one made on a wholly different method by Dr. Leone Levi in a paper read before this Society in 1872, wherein he considers that 846,000 persons were thus occupied; bat then he does not reckon with these either those who have to labour for that which pays for the imports, or those who provide for the maintenance of the alcoholic workers. Were these added his computation would exceed mine.

We are thus led up to the conclusion that one-tenth of the producing power of the country is labouring solely for the production of alcoholic beverages. The Jewish lawgiver ordained that one-tenth of the earth's produce should be given for religious uses. Our own forefathers set apart one-tenth of that which the soil brought forth for the church and the poor. In these modern days Christian England devotes one-tenth of her producing power-the hard labour of her toiling sons and daughters-to providing for the wants of the votaries of Bacchus. Such is the cost at which our consumption of alcohol is procured, and if we wish to represent this in a money form, we must take some one or other of the estimates which have been formed of the annual national earnings of the working classes. Dr. Leone Levi has assumed these to be 418 million pounds, one-tenth of which would be 42 millions-not far from the sum which he assigns as the cost of home production and foreign importation together, viz., 42,800,000l. Other authors 
have stated different amounts-Mr. Dudley Baxter 8I3 million pounds, and Mr. Gladstone 1,000 million as the total income of the nation. From these various sources we may safely conclude that its cost cannot be more than 100 million pounds or less than 50 million. This is stating the matter from the total abstainers' point of view, who see in it an entire loss of national wealth. The present is not the time or place for discussing how far these views are sound. but the statement of the total cost, whether expressed in lives or money, will furnish each individual with the means of judging to what extent his own practice may be forwarding or retarding that which he judges best for the welfare of the nation.

\section{IV.-Revenue from Alcohol: Rereipt and Disposal.}

Having thus endeavoured to ascertain what portion of the nation's strength is consumed in the production of alcohol, it may be convenient before inquiring what farther waste ensues upon the consumption of this same alcohol, to consider the matter in regard to the revenue derived from the taxes which have to be paid prior to its reaching the mouths of the consumers.

Table II already given sets forth the amounts raised in the several years from 1854 to the present time. For the reasons previously stated, there may be some doubt whether the $28,840,000 l$. shown for 1881 is the exact sum then contributed to the exigencies of the State by the consumers of these liquors, but it is quite near enough for our present purpose. It is often charged against our fiscal system, that there is something immoral in raising the revenue from such a source, and that the money so obtained is tainted with the vice of those who are its chief contributors. A moment's reflection will show that inasmuch as the effect of raising the cost of the liquor can have no effect whatever in increasing its use; there can be no moral defection in making those who will thus spend their means, pay heavily to the exchequer, which has to sustain so much of the cost entailed by the repression and punishment of the evils wrought by intoxication. So far as the imposition of the tax can have any influence at all upon drinking, it must be to lessen rather than increase it, and the higher the impost the more surely must it act in this direction : provided always that it does not lead to illicit distillation, and thus promote concealed instead of open consumption. There is, however, a somewhat widespread impression that the efforts of temperance reformers are adverse to the interests of the Exchequer, and that were these labours to be crowned with success, the Minister who is charged with providing the ways and means of meeting the national expenditure, would be puzzled from what source to raise the money which is now so easily procured through the agency of the brewer and distiller. This difficulty 
would no doubt be real; but if, as would undoubtedly be the case, the coin intercepted in its passage to the national purse, would still remain in the possession of those by whom it was saved, it would be but a tax upon the ingenuity of the chancellor how to find fresh means of transferring it from the one to the other. This could not be an overwhelning task, when it is remembered that the money reserved from drink and spared from the losses occasioned by drink, would render the ratepayer better able to meet the demands coming upon him in some other shape. For every sovereign rescued from the excise or customs officer's grasp, there would be two or three available for contribution through other channels. But whilst the State cannot be acting immorally in taxing the drink itself, it may be decidedly in the wrong if it does anything to encourage drinking or neglects any means within its power of discouraging this vice. This consideration opens up the wide question of the proper control which ought to be exercised over the number and character of the places where drink may be procured, and the temptations thus offered to increasing the consumption by which the Exchequer is swelled. This subject is for statesmen and philanthropists to settle upon moral and religious grounds : but it may well help their judgment and action if the statistician can show that in truth the major portion, if not the whole, or more than the whole, of the taxes raised upon alcohol is expended in counteracting the evils which its consumption entails; and that in reality the public chest would be betier filled if there were no alcohol on which to levy a duty.

The following items extracted from the civil service estimates for the current year, and the latest records of the sums raised by local taxation, show the sums voted for the maintenance of several branches of the public expenditure which are closely connected with the consumption of alcohol:-

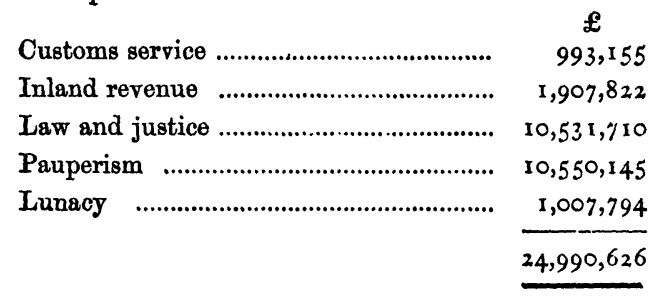

Their total almost exactly coincides with the customs and excise collection, if we add to them a not unreasonable share of the army and navy rotes, which include the cost of liquor supplied to our troops and ships; the loss of force from what amount of intoxication is indulged in by our soldiers and sailors; and the increase in the numbers necessarily maintained in support of the civil forces to protect the revenue, to preserve order and punish crime. Who 
can doubt, for instance, that if the Irish people drank no whisky, the poverty and the consequent troubles now existing would speedily cease?

It is by no means intended to assert that the whole of the charges upon the State funds enumerated in this extract would cease if intemperance came to an end; nor is it easy to say what proportion of them is in all cases due to drinking. Of the Customs and Inland revenue it is not difficult to pick out the amounts which are spent in collecting the duties on spirits, wine, and beer. They are as near as may be one-half of the whole vote. We have the testimony of our judges, magistrates, and police officers, that some eight or nine-tenths of the crime and pauperism which exist are due to intemperance. Our medical men assign a large portion of the lunacy which comes upon adults, and of the idiots and imbeciles who are so born or become so in infancy owing to the depravity of the parent or the neglect of the nurse, to the effects of drink. It must then be deemed a very moderate estimate if we assign onehalf of the cost of law and justice, of pauperism and lunacy, to the crime and the poverty which intemperance occasions. But this is not all : each criminal has his one or more victims whose life, health, property, or time he destroys or wastes. No one who has ever attended our criminal courts, but must be aware that the expense borne by the State in the apprehension, trial, and punishment of the wrongdoer is but a portion of the cost of his crime. Again, no one who knows anything of the private expenditure in meeting the poverty, sickness, and distress resulting from drink, either to the drinker himself or to those whom he injures, but must feel that it at least equals in amount that which the parish officer or other functionary distributes. Witness our hospitals, our asylums, and the alms entrusted to our clergy and other dispensers of charity in food, clothing, and medical aid. Now all this is just as much a loss to the nation as if it were raised by taxation and expended by the State. It is the product of voluntary rating, and thus a true contribution, in magnitude sufficient to meet all the other portion of the charges to which the table relates. It can scarcely be denied that thus an amount as great as the whole revenue derived from the taxation of alcohol is actually expended becanse that alcohoi is consumed. The guardians of the public funds need feel no apprehensions at the decline of the revenue from the spread of temperance, being fully assured that for every penny thus lost to the Crown, there will be either an actual reduction in the charges which absorb that revenue, or on the pockets of those from whom it is obtained, which will enable them without loss to supply by other imposts that which the State requires for meeting the remaining charges. Time will not suffice to go into the minute details which 
the rigid statistician may demand : but this is not the main issue set down for trial on this occasion, and I proceed to the second part of the investigation, viz., the waste of the nation's strength, the expenditure of its power resulting from the consumption of a]cohol.

\section{V.-Expenditure Resulting from Consumption.}

Coming to the consideration of this part of the subject, it must be confessed that the data on which to found thoroughly accurate conclusions are not yet within our reach. It has not been long enough deemed worthy of inquiry, nor have researches been deep enough to procure a sufficient body of statistics. They are only now being made; but such as are obtainable are worthy of attention, if it were only to define the nature of the information required and to direct investigation into the proper channels. Neither have I had time to gather together all that is to be procured, nor would there be space in this paper to fully discuss all that I have. The details of the recently taken census will supply some of the requisite evidence, and when these are fully published the whole question may again be taken up. In the meantime we are not without sufficient facts to guide us very near to what must be the truth, and to show that it must be worth ascertaining.

No one doubts that the undue indulgence in the use of spirituous liquors is the source of much crime and pauperism, sickness and death, destruction of property and waste of time and substance, nor that these affect not only the welfare of those who are in fault, but those who are connected with them or exposed to their influence, and thus most seriously trench upon the economic wellbeing of the whole community. To how great an extent this may prevail must at present be very much a matter of opinion, yet from the concurrent testimony of many competent observers, it is quite possible to arrive at a tolerably correct estimate of the various ways in which the nation's strength is thus wasted.

Dr. Norman Kerr has devoted much time and thought to the discovery of how many premature deaths may be assigned to this cause. The grounds on which he has proceeded, with the results of his calculations, have been brought before many medical and other assemblies without drawing forth adverse statements or opinions.* The direct mortality from personal drunkenness he puts at 40,500 , although his belief is that the true mortality for the United Kingdom is more likely to be between fifty and sixty thousand. Then as to the indirect mortality, from accident, disease, violence, and starvation, through the intemperance of other than the killed; it seems to him that for every personal drunkard that dies, two

* "The Mortality from Intemperance," June, 1879. 
innocents die also. Of these he assigns some 65,000 to infantile deaths, the remainder to adults. These estimates were for the year 1876 , in which the recorded deaths were $676,76 \mathrm{r}$. It gives an excess of deaths over those which would occur were it not for alcohol, amounting to between one-fifth or sixth of the whole number, or if we except the infants, to one-tenth.

But sickness precedes death, and prevails at all periods of life. Dr. Andrew Clark asserts that of the patients coming under his observation in hospital practice, 70 per cent. owe their presence there to the use of alcohol, and he ascribes very nearly a like proportion of the disease amongst his fashionable patients to the same cause. In a paper by myself, on "The Finance of National "Insurance," which will be found in the Journal of the Social Science Association for $1880,{ }^{*}$ a table of sickness at each age, as derived from the experience of friendly societies and other sources, is given. From this it would appear that the sickness of those at the working ages 18 to 65 averages about ten days per annum-say 3 per cent. of the working days-and this agrees well with that which has come under my own notice in one branch of the public service. These of course exclude the bulk of those who are the victims of intemperance; but applying it to the $10 \frac{1}{2}$ millions of producers, it would show that sickness is equivalent to a reduction of numbers to the extent of 315,000. Now if we say that only onehalf as much as this is occasioned by the consumption of alcohol, we shall have at the very lowest computation 150,000 of our producing class at one time incapacitated for labour from this cause. Surely a very moderate reckoning, when it is borne in mind that 600,000 inebriates-only four for each place for the sale of liquorare supposed to exist in the kingdom. These must be mainly amongst those who ought to be producing by their labour. They are calculated to die at the rate of $5 \frac{2}{5}$ per cent. per annum, and their unfitness for work must go a long way to making up the above allowance. Excluding those who are retarned as belonging to the "indefinite or non-productive," class, numbering $13 \frac{1}{3}$ millions, there are found to be a little over 8 millions on whose health and vigour the maintenance of all depend. Of these, $10 \frac{1}{2}$ millions are, as we have seen, deemed to be producers, but the labours of the other $7 \frac{1}{2}$ millions are no less necessary in ministering to the wants of those actually engaged in producing and administering that which is produced. Amongst these, consisting largely of wives and women engaged in household duties, there is, unhappily, too much drinking, and also a large number whose health is impaired by the want of sustenance and comfort occasioned by their dependence on

* "Trade, Population, and Food," pp. 326-44. 
the men who do drink. In like manner the infants whose lives are sacrificed to the maladies inherited from drinking parents, or resulting from deficient nutrition and attention, absorb the time and strength of those to whose care or neglect they are committed. Thus the infants themselves, although in no sense adding to the nation's strength, actually detract from it in the persons of others, and putting this together with the loss of power both before and after their birth-incident to the maternal functions and the breakdown of health arising from the circumstances in which the mothers are thrown at the season of weakness-it is not too much to say that fully an equal allowance of sickness must be made for these two classes as for that of the producers. As nearly as possible onefifth of the existing population are not more than 7 years old, this would give $5 \frac{1}{3}$ millions. Adding these to the $7 \frac{1}{2}$ millions of workers, though not producers, we get nearly 13 millions, for whom an allowance in the same proportion would give 185,000 as at one time incapacitated from working by their own sickness or that of the infants whom they have to attend to-in hoth cases as the result of intemperance. In all this there has been no estimate of that enfeebled health which, in the experience of all, lessens the power for labour, whether in productive occupations or in those of a ministerial nature, to a far greater extent than do the days of enforced abstinence by illness.

Since writing the foregoing, I have met with a passage in a report to the registrar-general in 1875 , by Dr. Farr, which completely supports the computation made in respect to the proportion of sickness to death:- "It has been found by experience that in " England, to one annual death in a body of men, two are on an " average constantly suffering from sickness of some severity. "There are two years of severe sickness on an average to one "death. In the police and in some friendly societies the con" stantly sick to one annual death are $2 \cdot 8$; in the army at home $4 \cdot 2 . "$ On this reckoning 120,000 deaths multiplied by $2 \cdot 8$ would give 336,000. My calculation is 335,000. Dr. Farr goes on to say that since the deaths for the year of which he wrote were 700,000, there must be I, 400,000 constantly suffering from severe disease, and 2 millions from such sickness as would bring them within the range of Friendly society relief. The proportion of these whose sickness Dr. Andrew Clark would attribute to intemperance, far exceeds the numbers above given.

There is an overwhelming amount of testimony from the clergy, guardians of the poor, and the visitors and agents of philanthropic societies, to the fact that pauperism is due more to drinking than any other cause-not always that of the paupers themselves, but of those on whom they are dependent. Seventy-five per cent. of 
those who are thus supported at the public expense admittedly owe their position to this cause. Nearly if not quite the same may be said of lunatics, idiots, and imbeciles, and those who have lost the power of sight, speech, and hearing, and are thus prevented from fully or at all contributing to their own support. The census of 1871 shows the following numbers in England and Wales :-

\begin{tabular}{|c|c|}
\hline 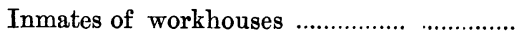 & $148,29 \mathrm{I}$ \\
\hline hospitals & $19,5^{8} 5$ \\
\hline Lunatics ……............................ & 39,567 \\
\hline Idiots and imbeciles ...... & $29,45^{2}$ \\
\hline 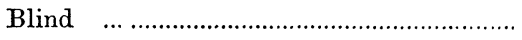 & 21,590 \\
\hline 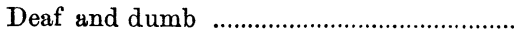 & II, 518 \\
\hline & 270,003 \\
\hline
\end{tabular}

Possibly some of these are reckoned twice over, but we cannot greatly err if we assign one-half the number to the prevalence of intemperance, and adding in proportion to the population, which in Scotland and Ireland together was 40 per cent. of that of England, we shall have $135,000+54,000=189,000$. This number may be increased by i 1,000 , the one-half of the union and parochial officers, chaplains, and others attached to or visiting these institutions, bringing up the total to 200,000 , without at all calculating the numbers who, as the distributors of private charities, have their time devoted to the same objects.

Of the criminal classes, we have the decided expression of Chief Justice Coleridge, backed by the authority of numberless justices of the peace, chaplains of gaols, and prison officers, that eight-tenths of the crime brought to judicial notice is the offspring of drink. This entails the employment of police, prison attendants, \&c., besides that of judges, magistrates, and officers of the law courts, who are thus numbered in 1871 :-

\begin{tabular}{|c|c|}
\hline Inmates of prisons ..... & 28,756 \\
\hline Prison officers & $3,75^{\circ}$ \\
\hline 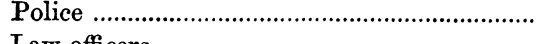 & 28,330 \\
\hline Law officers & 2,336 \\
\hline & 63,172 \\
\hline Forty per cent. for Scotland and Ireland .... & 25,268 \\
\hline & 88,440 \\
\hline
\end{tabular}

Now when it is recollected that much criminal misconduct escapes punishment, that every act of crime destroys life, health, or property, and involves loss of time, which might be devoted to useful labour, in its detection, conviction, and punishment (often in the shape of fines), in addition to that of the actual sufferers; it is 
safe to assume that but for the effects of the drink which occasions so large a share of these offences, the nation would be saved a loss fully equal to the whole of the numbers thus stated.

There is yet one more consequent loss in the services of professional and other persons, who might be spared were it not for the occurrence of sickness and death, poverty and crime. The same census return enumerates :-

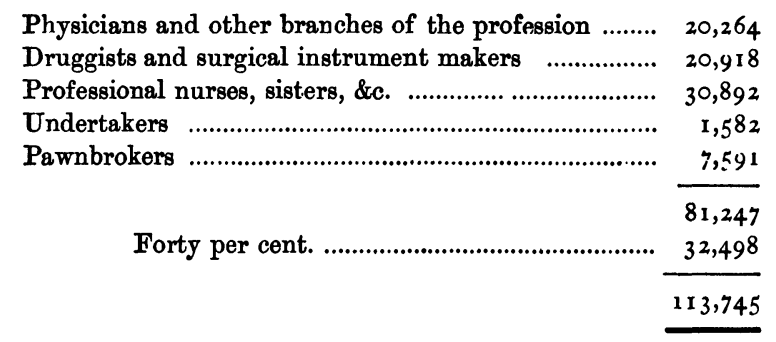

Surely 50,000 of these is not too many to include in the computation.

Further than this the Civil Service Estimates for the present year fix the Customs establishment at (including a calculated portion of the fluctuating employés) 6,583 persons, and that of the Inland Revenue at 5,948, together 12,53 I, of whom for the same reason as one-half the cost of these departments was assumed to be chargeable to the collection of the imposts upon alcohol, we may set down 6,000 persons as thus employed.

Finelly, the army and navy have oftentimes to support the civil power, and the seamen of the merchant navy are engaged in the transport of alcoholic liquors. Their numbers in 1871 were :-

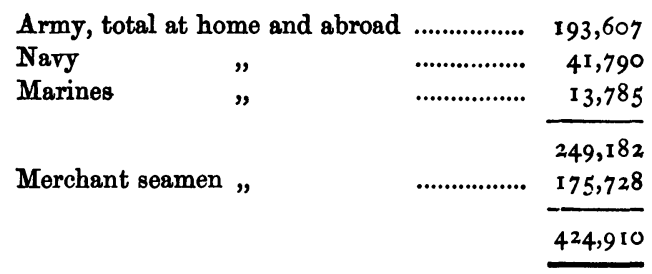

These are all subject to the same temptations to indulgence in drink, and the same vicissitudes as to health and employment of time as others are, and did they not yield or succumb to these, their efficiency might be increased, or their numbers be diminished most certainiy by 10 per cent. At least another ro per cent. may be charged for their occupation in various ways, in consequence of the drinking of others. This would give say 85,000 .

All these estimates are confessedly more or less arbitrary, yet 
they are consonant with reason, and will to those who have examined carefally into the cause and effects of the national use of alcohol, appear to err on the side of moderation rather than exaggeration. This will especially seem to be the case when it is remembered that no effort has been made to include the loss of time and exhaustion of strength in the fetching, carrying and consuming of the liquor by those who partake of it, nor yet of the consequences short of crime, \&c., which flow from the state of intoxication, or of that approach to it which lessens self-control and inclines to evil, especially that severe form of it to which the streets of our towns bear nightly witness. Yet all these, as in fact does every form of moral delinquency or perversion, have an important bearing upon the economic condition and prosperity of the whole community. It will be observed that all the calculations as to waste of power are of the assumed loss from what all will admit to be the undue use of the alcohol. Against these, in the opinion of many, there will be a set off in the good effects which are believed to arise from its moderate use and enjoyment. Abstainers will not admit that these can be more than infinitesimal in amount, but conceding for argument sake, that they may be appreciable or even largely beneficial, they certainly cannot outweigh the unappraised evils to which allusion has been made. The preponderance of harm and loss must certainly be found on the side of use rather than of abstinence.

To sum up the several items of expenditure, not in money but in numbers, we have an annual sacrifice of-

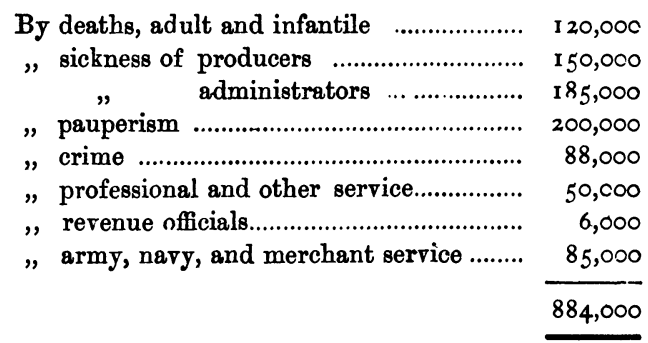

Add these to the $1,097,525$ previously shown to be engaged in the production of alcohol, and we have very little short of two millions of our adult population employing or wasting their lives in this one direction. One-tenth of the vital power which maintains our population and accumulates our wealth, engaged in manufacturing that which in its use employs and destroys that same vitality in onetwentieth of the people who are of sufficient age to become consumers. Ten per cent. of all our adults rendered economically helpless and useless by reason of our national taste for drink. 


\section{VI.-Loss of Capital and Power.}

No reference has been made to the devotion of capital and skill, with the appropriation of both of which to such a purpose the economical use of the national resources is concerned, for the reason that supposing, as we must, that these are employed in the same proportion as the persons are, the numbers will furnish an indication of the national expenditure in this as it does in vital power. Startling as the conclusions arrived at are, there seems to me no reason to doubt their accuracy, and if not, it is evident how seriously they must affect our views as to the effect they have upon our present social condition, and the prospects to be entertained of our future economic progress. The devotion of so large a number of our people to this one branch of manufacture assumes a more serious import from the fact that of the $10 \frac{1}{2}$ millions of producers 65 or 70 per cent. are wholly employed in providing the food, drink, and necessaries of life for themselves and their fellow countrymen. It is the remainder only, that is, some $3 \frac{1}{2}$ millions, who are applicable to the production of luxuries or the accumulation of wealth. If there were no alcohol to be produced or consumed there might be 2 millions more, an addition of 60 per cent. to our power of procuring articles other than for daily use or for adding to our existing stores. How much of increased happiness might result, or how much more might be laid by? If it be said that with an ever increasing people there might be a difficulty in finding employment, the answer is that they might as well be resting as working for that which is useless; or that elsewhere, if not in this country, there is abundant scope for employing more labour, more skill, and more capital, than we have to spare at home. Our export trade might be cheapened if the workers employed in it saved the percentage now spent in drink, and our colonial possessions peopled, mutually to their advantage and ours.

\section{VII.-Conclusion.}

In conclusion, it may be asked whether this is not truly the question of the day, one that demands the efforts of our legislators in lessening the temptations to indulgence by restricting and controlling the houses in which intoxicants are sold; one that calls upon our social reformers and philantbropists for renewed and persevering exertions to check the spread of intemperance and reclaim its victims; one that justifies-if it does not demand that all should follow their example- the self-denial of those who, that their influence over others may be increased, altogether abandon the use of alcohol themselves, and will never rest from their labours until the country is purged from its national sin. We occupy ourselves much 
in discussing the topics of imports, exports, the balance of trade, and the relative advantages of fair and free trade, forgetful that in our midst there lurks an evil whose removal would set at rest all these difficult and disturbing questions, and give us such a new lease of prosperity as to quench all desire for a change in our fiscal system. We deplore our losses from deficient harvests as well as from diminished trade, whilst the cancer which is eating into our vitals consumes in one year more than we lose in two from combined agricultural and commercial depression. If agriculture is to prosper, trade to flourish, or social, moral, and religious progress to be made, we must speedily reform our drinking customs, and arrest the growth of national expenditure upon alcohol. 


\section{Discussion on Mr. Bourne's Paper.}

Professor Leone Levi said they were greatly indebted to Mr. Bourne for his very able, temperate, and judicious paper on a subject of great importance, on which it was very easy to enter into sentiment, but upon which also statistics might give a great deal of light. It was a relief to learn that the amount expended by the nation in the production of alcoholic liquor did not amount to so large a sum as had been put forward again and again in the "Times," amounting to 123 million pounds; that representing to a large extent the gains of the distributors, the taxation imposed upon alcoholic liquors, and the expense of distribution. From calculations which he had made, contained in a "Report on the Appropriation of Wages and other Income," presented to the British Association in 1881, he found that the gross amount expended by the nation in these articles was 32 or 33 million pounds, and taking the real cost of distribution at 10 per cent., it came altogether to 36 million pounds, or about one-third of the total amount said to be expended by individuals on these liquors. But then the very important question arose, what proportion this amount constitutes on the total annual expenditure of the people? The total expenditure was by him estimated at 684 million pounds a year net and 878 million pounds gross. Upon the total gross expenditure, therefore, the gross expenditure upon alcoholic liquors, including taxes and the profits of distribution, was about i3 per cent., but upon the net expenditure the proportion was about 6 per cent. only; so that the proportion devoted to this item was not so very large as one might imagine. Mr. Bourne had assumed that the total expenditure thus incurred was the cause of all the mischiefs which he had subsequently enumerated. The fact of the matter was that a very large proportion of the consumption of these alcoholic liquors might be termed temperate, while a very small proportion represented the intemperate. But most, if not all, the consequences referred to as to lunatics, prisons, and pauperism arose not from the total expenditure, but from the portion of that expenditure which was really consumed in excess and by those who were intemperate. It was very difficult to ascertain the proportion of the temperate expenditure to the intemperate. When $\mathrm{Mr}$. Hoyle read the paper referred to at York, he ventured off hand to make a statement to this effect: there were say 280,000 persons taken up for intemperance in the United Kingdom; assume these to represent 280,000 different individuals, which they did not, because the same persons were taken up time after time; multiply these by five, that is on the supposition that every intemperate case taken up by the police represents five persons given to intemperance; that would represent about $I \frac{1}{2}$ million persons, or say one twenty-fourth part of the population. A twenty-fourth part of 36 million pounds would be 
$1,500,000 l$., that would be the real cost of the intemperate expenditure in the country. In all branches of expenditure a clear distinction must be made between the necessary, the luxurious, and the really wasteful. Of course there was a very large abuse of drink in various ways-in a luxurious manner at public dinners and in society generally, but that could scarcely be considered in an economic sense as absolntely wasted, or as the direct cause of those mischievous consequences that had been referred to. Then again, when they came to the mischievous consequences, the difficulty was to ascertain the immediate as distinguished from the remote consequences of drink. For instance, Mr. Bourne stated that a very large proportion of lunatics became so in consequence of intemperance; but the commissioners of lunacy stated that the proportion of those who became lunatics or idiots from drink was last year only 12.6 per cent. Then again with regard to crime, he found that of the number taken up by the police in England for summary jurisdiction offences, those taken up for intemperance amounted to 26 per cent., a very large proportion, but not unehalf. Then coming to the higher crimes in England, by far the largest proportion were crimes against property, and not against the person. The direct consequence of drunkenness was to incite to crimes against the person, though indirectly by producing want and misery it might lead eventually to crimes against property; but still the proportion of offences in England was 15 per cent. against the person to 85 per cent. against property, and those which on the widest possible hypothesis could be ascribed to drink did not amount to anything like what might be deduced from the author's statement. In 1880 there were fifteen cases in which the capital sentence was carried out; of these, four arose from jealousy, four from dissensions in families, two from cupidity, one from debauchery, one from revenge, and one from homicidal mania. Similarly in the fifteen cases where the penalty was commuted, eight arose from robbery, two from dissensions, two from drink, two from debauchery, and one from desertion. To what extent any of these might in a more distant or remote manner have been the result of drunkenness of course it was impossible to say, but these figures would give an idea of the causes of crime. Then again in the matter of pauperism, doubtless a very large proportion arose from drunkenness, but he believed that a very large proportion of the pauperism of the country was hereditary; a large proportion also arose from sickness in the family and from want of work, due to circumstances of trade. Another important cause was the want of thrift. Of course if the people were more thrifty, and if the means for saving were multiplied there would be less drunkenness; but to say that the whole or any large proportion of the pauperism arose directly from drunkenness was rather beyond the mark. Then as regards the mortality arising from drunkenness: the registrargeneral's report told us that in 1880 the deaths from alcoholism, viz., delirium tremens and intemperance, or deaths directly ascribed to drink, numbered 950, whilst 152 violent deaths were returned as having occurred while the parties were in a state of intoxication, or suffering from delirium tremens, altogether 1,102 upon a total of

VOL. XLV. PART II. 
upwards of 500,000 deaths. He was very sorry to offer any remark which seemed to diminish the importance of the facts brought before them. It was impossible to flatter themselves that the evil did not exist; it did exist, and it was their bounden duty to do their utmost to diminish it; at the same time it was important to find out the truth of the matter, because friends were never gained to a cause by bringing forward exaggerated facts which could not be supported by careful investigation.

Mr. Hepple HaLl said Mr. Bourne had given them a most suggestive paper. There were two statements in it to which he wished to draw attention from a statistical point of view. At the foot of Section B the author spoke of 896,408 as the estimated number of the people whose occupation it is to provide the liquor consumed in the land. These figares are further increased to $1,097,525$ by the proportion of the whole population required to sustain, house, and clothe the workers in alcohol. $\mathrm{He}$ thus arrived at the conclusion that one-tenth of the producing power of the country was labouring solely for the production of alcoholic beverages. The care with which Mr. Bourne invariably considered his figures, made him (Mr. Hall) hesitate before challenging any of them, hut surely he had not taken into consideration the fact that the labour employed in the supply of alcohol would, if it had not that means of employment, either go to swell the large and growing class of the unemployed or would become fit subjects for emigration. No suitable channel of employment was open to them in this country. The other passage was one in which Mr. Bourne gave items extracted from the Civil Service estimates of the current year, and showed sums amounting to nearly 25 million pounds as coinciding with the Customs and Excise collection. Here again he would suggest that Mr. Bourne had perhaps laid himself open to some slight charge of inaccuracy. In another part of his paper he attributed all the ills of the Irish race to the habit of drinking whisky. He (Mr. Hall) would respectfully submit, with all his horror of whisky, and especially of Irish whisky, that in this matter Mr. Bourne charged Pat with a crime he was scarcely guilty of. The troubles existing in Ireland had a far deeper root, and a very different source than the whisky. Looking at the whole subject, he was inclined to agree with Professor Levi that they must exercise a just and fair discrimination in dealing with these great questions, in order to form a right conclusion with regard to them.

Rev. Dawson Burns said he believed that the estimate of 130 million pounds as being the average annual expenditure upon intoxicating drink for the last ten years was by no means an exaggeration, and in dealing with this question, if they diverged from the point of simple expenditure into the question of the relation of that expenditure to the economical state of the nation, it was a fair subject for consideration how far the appropriation of that enormous sum of money in the purchase of other things than alcohol would affect the condition of the country. That seemed to be the vital 
essence of the whole question. They did appropriate 130 million pounds annually to alcohol; supposing that were not so appropriated but were otherwise used, what would be the effect upon the industrial, moral, soeial, and economical condition of the country? Both Mr. Bright and Lord Derby, in speaking on this topic, had expressed the opinion that if only one-half the drinking were given up, the condition of England would be so much altered for the better, that it would scarcely be recognised as the same country, and, knowing as some of them did, the effect upon families when they changed in this matter, he could say deliberately that it was impossible to exaggerate the improvement that would take place, if even a large proportion of that expenditure were otherwise directed, and how much more so if the whole were otherwise used. With regard to the criticism of Professor Leri and Mr. Hall, he might say that on the question of the loss produced to the country, they must take the opinion formed by the experience of those who were brought into immediate connection with the people. The judges had no interest in exaggerating, neither had those in charge of prisoners any motive for misrepresenting the proportion of crime that was owing to strong drink. There was no undue disposition on the part of guardians of the poor to say that 75 per cent., instead of 20 or 30 per cent., was the proportion of those who were brought under their care through intoxicating liquor. Professor Levi had deplored the want of thrift, but was not this largely due to that other cause of intemperance lying behind it; and as to the wasteful expenditure upon drink, admitting that there was a distinction between what was termed the temperate and the intemperate use, who wonld pretend to say that the intemperate expenditare, interpreted in the most liberal sense of that term, did not enormously exceed that proportion which Professor Levi had laid down? If the Professor was compelled to visit every public house in London that night, and to estimate what was the intemperate expenditure upon alcohol in all those houses, and if it were possible for him to extend his visits to the whole country, no doubt he would very much alter his conclusions. Who could pretend to say that the drinking going on in London that night was temperate? If gentlemen would examine into the condition of the working classes, and see what an enormous amount of their money was wasted on strong drink, they would find that the calculations made by Mr. Bourne were very much within the mark. Besides, he had made no allowance for what was an enormous loss to the country, namely, the want of punctuality in work caused by drink. He knew a gentleman connected with employment of labour, giving work to more than 60,000 men in various parts of the country, and he stated that their loss from this one cause was enormous with the men who took to drinking or did not come to work on account of previous drinking. That great item of econonic loss did not enter into the account which had been laid before them that night. He believed the representations made by the reader of the paper were most reasonable, and a more thorough investigation of the whole facts would show that the statements made were under the actual facts rather than beyond them. 
Rev. Canon Eluison said if be understood Professor Leone Levi aright, he thought the proportion of temperate drinking to intemperate was very much larger than was generally allowed, and he gave some figures in illustration. He (Canon Ellison) approached the subject from a somewhat different point of view. He had been for more than forty years a parochial clergyman, for twenty years in a large town, and his experience showed that taking the ordinary statistics of crime which came before the public eye, and comparing them with what he had seen going on in the homes of the people, so far from Mr. Bourne's figures being at all in excess of the truth, they fell very far short of it. He believed the real truth was that the amount of intemperate drinking was very far in excess of what the public at large had the least idea of, and he might illustrate this by one or two figures. In the House of Lords' inquiry, Mr. Wayland, a missionary to public houses in the east of London, was asked what he thought would be the proportion of drunken people to the drunken people who were taken up by the police, the instructions to the police being that they are never to touch drunken people unless they are either noisily or obstructively drunk. His reply was that the proportion would be 50 to I. That evidence was rather borne out by Mr. Chamberlain, who gave some very alarming figures. He said a certain number of public houses in Birmingham were watched on a Saturday night, and the number of people given who came out of those public houses, and then the number of those who were drunk. Taking these as fair specimens of the whole of the public houses in Birmingham, it was calculated that there were 40,000 dranken people in the streets on a Saturday night. The members of the committee were so startled with this, that they asked $\mathrm{Mr}$. Chamberlain to consider the different conditions which might be taken as qualifying a statement of that kind, and he therefore threw out certain figures which might have seemed to come in unduly to enlarge the estimate, and at last he said, "I should think on the whole probably there would be about 5,000 drunken persons in the streets of Birmingham that night." On that night there were only twenty three taken up by the police, giving a much larger estimate than Professor Levi took when he said that for one intemperate person taken up by the police you might reckon that there were five others intemperate who were not so dealt with. He was afraid the number would be found much larger than that. Then again, when they spoke of the indirect as compared with the direct results, he believed that the indirect results were far more important than the direct. He referred to the numbers that he had seen who had been sent to lunatic asylums, or children made idiots, or those who had suffered in one way or another whose cases never would appear in figures. A few years ago in the report of the Durham Lunatic Asylum, the superintendent said that of the women who were there the greater number had become inmates through the cruelty of drunken husbands. He did not believe that those who were accustomed to judge of these things merely in relation to percentages, or to the number of those who came under the notice of the authorities, had the remotest idea of the real amount of intemperate drinking in the 
country, and he was very thankful to have heard certain conclusions brought out as they had been by Mr. Bourne.

Mr. D. MacIver, M.P., said he entirely concurred in Professor Leone Levi's opinion, that but a comparatively small proportion of the drinking in the country was intemperate drinking; still on the other hand he could not help thinking that there was a good deal of absolutely wasteful drinking, which although it might not result in actual drunkenness and crime, was yet on the side of evil, and not on the side of health. His experience as a magistrate showed that the same people were taken up for drunkenness again and again year after year, until they became almost old acquaintances, and that rather led to the conclusion that the percentage of the population which was intemperate was smaller than Mr. Bourne had indicated. Although he was entirely in harmony with the intentious of the author, and although every one must have met with many cases in which the evils and miseries produced by drunkenness could not possibly be exaggerated, yet he thought that the paper contained in many points language of exaggeration, and however good the intentions might be, that, after all, was not the way to further the cause of temperance. For instance, with regard to the Irish and their whisky, he did not think such a statement as that made by the author was tenable for a moment. Then with reference to the national revenue, it must be remembered that most of the charges on the revenue were fixed charges-such, for instance, as the interest on the national debt-and could not possibly be diminished, even if the drink traffic, with its attendant evils, were entirely to disappear.

Mr. GrFFEn said there could be no question that Mr. Bourne had thrown a great deal of light upon this subject. One point which seemed to come out with a good deal of clearness was this, that Mr. Bourne's investigations confirmed the estimate made by Mr. Hoyle, that the amount paid for the production and distribution of alcohol annually was from 120 million to 130 million pounds. The actual cost of the production of the raw materials used was stated at 22 million pounds; the people engaged in producing the raw material were only one-third of the total number concerned in the manufacture and distribution of the article, so that multiplying the 22 million pounds by 3 they came to a figure of between 60 million and 70 million pounds; then adding 30 million pounds for taxation, they came to a figure of over 100 million pounds; and that calculation corroborated to a very considerable extent the sum of from I20 million to I30 million pounds, at which Mr. Hoyle and others had arrived. They must not expect to get extreme accuracy in these matters, but when independent investigators, working by different ways, arrived at such very large figures, they might be quite safe in assuming that the lowest of them was within the mark. Going beyond this point, there could be no doubt that the question of the loss to the country by the consumption of alcohol was an entirely different problem, and in its consideration the question suggested by Professor Levi, as to what was temperate and 
intemperate, came into view. It was quite open to those who maintained that every kind of consumption of alcohol was waste, to argue as Mr. Bourne had argued, that one-tenth of the power of the country was really engaged in this business, and if they assumed that the thing was an absolutely noxious article, the conclusions of the paper were established. But looking at the matter in a strictly economic aspect, he did not think the state of the evidence on the subject was such as to justify them in assuming, for purposes of economic discussion, that a large part of the consumption of alcoholic liquors was any more wasteful or injurious to the community than the expenditure for hundreds of other articles. If, however, with regard to any article they could say definitely that a certain part of the use of it was absolutely injurious to the people at the time ther were consuming it, and that it produced a certain loss of time, and disease and sickness resulted from its use, then there was an economic waste arising from the consumption of alcoholic liquors, which could be spoken of apart from any theories of total abstinence or the reverse, and this waste, which everybody must recognise, whether total abstainers or not, must be very large indeed. Professor Levi had very properly drawn attention to some calculations which might be made upon the statistics of crime and panperism, in contradiction to estimates which were made by those intimately acquainted with the condition of the people; but looking at the balance of evidence, he (Mr. Giffen) thought the very small percentage which the Professor arrived at was hardly supported, and they could not but come to the conclusion that of the roo million pounds, which must be admitted to be spent by the people on alcoholic liquors, a very large part was wasteful expenditure. Even if it were one-fourth only, or 25 million pounds, that was an enormous sum, and that was entirely irrespective of the waste to the country from crime and pauperism, which on Mr. Bourne's figures would not be less than another 25 million pounds. These two sums amounted to 50 million pounds, which was quite large enough to justify, in an economic view, all the complaints about the evils of intemperance, and the opinion that there would be an immense gain to the country if the evil could be removed. The consideration of what could be obtained with such a sum as 50 million pounds annually, quite justified the expressions of Lord Derby and others as to what the effect would be if they were a temperate people.

Mr. Bourne, in reply, said the observations of Professor Levi were directed, in the first place, to the fact that the intemperate use of liquor was small in comparison with the temperate. $\mathrm{He}$ (Mr. Bourne) did not much care to inquire whether it was small or large, if the results which he had depicted flowed from its use. It did not matter if only a tenth portion was so consumed if the amount of evil produced remained the same, and Professor Levi had not at all shaken the estimate he had made as to the results of the intemperate use. That pauperism was hereditary only bore out his argument, because it arose from the fact of the fathers having been drunkards, entailing poverty upon their descendants and disability to labour by the very fact of their indulgence in liquor 
beforehand. The Professor's remarks had been entirely directed to the charges of intemperance and not to the crimes caused by it. What the judges spoke so much of was not the mere fact that crimes were intemperate crimes, but that the original cause from which the crime sprung was the intemperate indulgence either by the individual himself or by others. Mr. Hepple Hall referred to the consumption of whisky in Ireland. $\mathrm{He}$ (Mr. Bourne) would not at all retract the statement he had made. There was no question whatever that the misery in Ireland arose in great degree from the pauperism of the people, and that in its turn was in a large measure the result of their intemperance. Seeing that it was capable of proof that in the worst year in Ireland more than the whole rental of the country was spent in whisky, he would assert that if the money had been in the pockets of the people, they would have been willing to pay their rents, and there need have been no difficulty or disturbance about it. Besides which, the hereditary tendency to idleness, and the stirring up of all the evil passions of human nature by the consumption of drink, went fully to bear out the observations he had made. Mr. Dawson Burns was rather disappointed that the question had not been put more as one of $£ s . d$. He had studiously avoided that course, because it was so very difficult to arrive at any notion of the absolute income of the country. The proportion spent in drink would not tell unless they could know the total sum, and therefore he beliered that the test of numbers was better than the test of money. He had drawn attention to the fact that it was only a proportion of the producing power of the country-he believed 30 or 35 per cent.-which remained available after satisfying absolute necessities, and if he was right in saying that $3 \frac{1}{2}$ millions or one-third of their producers were all that were now applicable for the purpose of creating articles of luxury or for accumulation, and then proved that 2 millions could be added to the $3 \frac{1}{2}$ millions, he at once showed that they could, after making ample provision for the wants of these by reducing the amount of the country's strength spent on intoxicating liquors, add at least 40 per cent. to the wealth of the country. It was therefore impossible to exaggerate the benefits which would result if they had an addition of 40 per cent. to that which they at present enjoyed. With regard to the point as to how the revenue was to be provided for, he had shown that at least one-half the revenue raised from taxation was expended because of the consumption of alcohol, and he had fairly assumed that the other half would remain in the pockets of the people. Then no one would grumble at additional taxation in some other form if it was true that the whole of the money so to be raised was saved by not having been expended in drink. The main object of his paper was to draw a distinction between the national and personal loss, because however much they might deplore the loss to the individual, yet the greater question for them to consider was the loss to the country as a whole. It mattered very little to the community whether one pocket held the money or the other; the question was how much was altogether sacrificed, and the 50 million pounds mentioned by Mr. Giffen was a very large item as affecting the welfare of the 
country. He felt much indebted for the kindly observations which had been made with regard to his paper. He believed the question was one of national importance, and deserved especial consideration at the hands of those who were charged with the government of the conntry.

The Prasident (Mr. James Caird, C.B., F.R.S.), in proposing a vote of thanks to Mr. Bourne for his very able and instructive paper, said, it having been admitted on all sides that the annual expenditure in alcoholic liquors reached 130 million pounds, he had endeavoured, in order to realise that amount, to bring it to a comparison with something which they could clearly understand, and he found in so doing that 130 million pounds was nearly double the whole land rental of the United Kingdom. 